$\mathbf{K}$ nusing av tabletter er noe som skjer hyppig i helsevesenet. En undersøkelse ved 19 sykehjem i Nord-Trøndelag viste at 42 prosent av sykehjemmene knuste over 20 tabletter daglig, og 15 prosent av total mengde knuste tabletter var depot- eller enterotabletter (1). Spiller det så noen særlig rolle om slike tabletter knuses? Er ikke det viktigste tross alt at pasienten får medisinen som er forordnet? Svaret er at det kan spille en svært stor rolle hvordan medisinene tas. Ordinering av legemidler er et legeansvar. Dette innebærer også å ta stilling til hva som skal gjøres når pasienter ikke får tatt tablettene slik Felleskatalogen angir. Sykepleiere er likevel de som møter problemet mest direkte i forbindelse med istandgjøring og utdeling av legemidler. I denne artikkelen beskrives de viktigste konsekvensene av å knuse eller tygge tabletter når dette er i strid med produsentens anbefalinger.

\section{Kraftig virkning}

Mange tabletter lages med depoteffekt, spesielt blir dette gjort der man ønsker jevn effekt av legemidler med kort halveringstid. I stedet for at alt tas opp fra tarmen med en gang så frigis legemiddelet gradvis, for eksempel over 12 eller 24 timer. Noen depottabletter er laget nærmest som en svamp der

\section{Hovedbudskap}

Mange pasienter klarer ikke å svelge tabletter hele. Sykepleier må da være klar over at knusing av tabletter kan ha stor innvirkning på legemiddelets effekt, og kan til dels være svært farlig. Redusert eller forsterket effekt, økte bivirkninger og helsefare for helsepersonell som håndterer medisinen er noe av det som kan skje.

\section{Søkeord}

Les mer og finn litteraturhenvisninger på våre nettsider. ) Farmakologi \Legemidler / Medisiner legemiddelet gradvis lekker ut. Slike tabletter kan ofte deles i to, men må ikke knuses. Andre depottabletter består av flere lag, der det ytterste laget løses raskt, mens en hard kjerne løses senere. Av depotkapsler må noen svelges hele, mens andre kan åpnes for å svelge kapselinnholdet. Det som alltid vil skje når depottabletter eller innholdet av depotkapsler knuses, er at alt legemiddelet frigjøres på én gang i stedet for å frigis over tid. Dermed får du umiddelbart en mye kraftigere effekt enn ønsket og med økt bivirkningsrisiko. Du får også en mer kortvarig effekt og dermed mye svakere effekt på slutten av doseringsintervallet.

\section{Kan være farlig}

Betablokkere og kalsiumantagonister finner vi ofte som depottabletter, med Selo-Zok og Adalat Oros som typiske eksempler. Den gunstige medisinske effekten er basert på at man holder seg innenfor et terapeutisk vindu mellom en øvre og en nedre serumkonsentrasjon. Ved knusing av tabletter vil dosen i stor grad komme utenom dette terapeutiske vinduet, dels over med økt bivirkningsrisiko og dels under med tilsvarende manglende effekt. For depottabletter av sterke analgetika som Oxycontin og Dolcontin vil knusing av tabletter være meget farlig, med økt risiko for respirasjonsdepresjon. Antiepileptika er også en legemiddelgruppe der mange preparater fins i depotform, for eksempel Tegretol Retard. For epilepsimidler er jevn og riktig dosering spesielt viktig, og knusing av depottabletter vil gi økt risiko for anfall og bivirkninger.

\section{Redusert virkning}

Noen legemidler nedbrytes og mister effekten ved kontakt med magesyre. For å unngå dette har en del legemidler enterodrasjering som først løses i tynntarmen. Dette gjelder blant annet alle protonpumpehemmerne, som reduserer syresekresjon i magesekkens slimhinne. Av disse er for eksempel Nexium-tabletter laget av et stort antall korn med virkestoff, der hvert enkelt korn er en- terodrasjert. Her gjør det ikke noe om tablettene deles eller slemmes opp i vann og drikkes så lenge de små kornene ikke tygges eller knuses. Omeprazol og Lansoprazol finnes som enterokapsler, og her kan kapslene åpnes og innholdet svelges så lenge kornene ikke tygges eller knuses. Det samme gjelder Ery-Max-kapsler som inneholder antibiotikum med enterodrasjering. Combizym inneholder fordøyelsesenzymer og må svelges hele for å unngå nedbrytning av magesyre. I tillegg vil tygging av tablettene frigi enzymer i munnen, og kan gi skader ved digestion av munnslimhinnen. Creon-kapsler er et lignende preparat der kapslene kan åpnes og innholdet blandes med mat så lenge kornene ikke ødelegges. Enkelte tabletter skal ikke svelges. Sugetabletter utøver effekten i munnhulen, og det er ønskelig med så langvarig kontakt som mulig. Sublingualtabletter som Nitroglycerin og Temgesic skal legges under tunga og virker ved at legemiddelet absorberes direkte fra munnslimhinnen. Svelges de vil legemiddelet raskt bli nedbrutt i leveren på grunn av svært høy førstepassasjemetabolisme.

\section{Flere bivirkninger}

Mange legemidler skal svelges hele for å redusere risikoen for bivirkninger. Sårdannelse i spiserøret er eksempel på bivirkning som kan oppstå for mange legemidler, og problemet forsterkes dersom tablettene knuses eller tygges. For benresorpsjonshemmere som Fosamax-tabletter er sår i munn og svelg et spesielt stort problem. Mange NSAID-er, slik som Voltaren er enterodrasjert for å redusere risikoen for ventrikkelslimhinneskader. Salazopyrin-EN og lignende preparater gir hyppig gastrointestinale bivirkninger i form av kvalme med mer, og enterodrasjering bidrar til å redusere disse noe. Mange cytostatika forårsaker skade i kontakt med hud og slimhinner, og for preparatene Hydroxyurea, Navelbine og Temodal må kapslene ikke åpnes, tygges eller løses opp i munnen, men svelges hele med et glass vann. Mangelfull ren- 


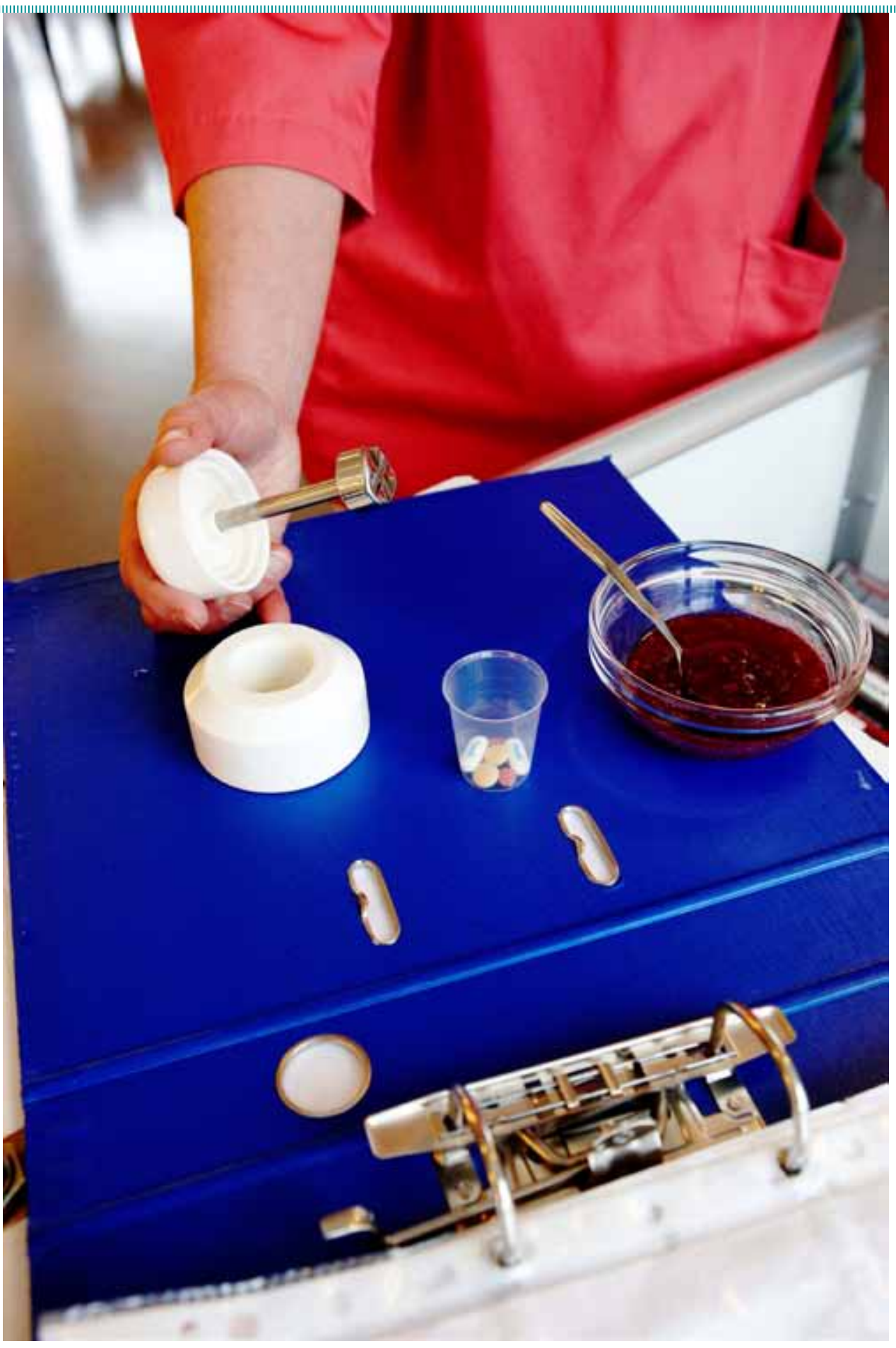

FORSKRIFTSMESSIG: Tabletter skal ikke knuses hvis dette er i strid med anbefalingene. Arkivfoto: Erik M. Sundt

gjøring av utstyr til tablettknusing kan generelt overføre tablettrester fra en pasient til neste.

\section{Helsefare for personell}

Hvis man knuser tabletter så vil helsepersonell lettere bli utsatt for støv og partikler fra legemiddelet, og spesielt gravide bør tenke på hva de utsetter seg for av kjemiske stoffer. En rekke legemidler inneholder stoffer som kan være skadelig for fosteret. Thalidomide, Neotigason og Isotretinoin er preparater som er kjent for å være svært skadelige for fosteret. Alle disse er kapsler beregnet på å svelge hele, og helsepersonell skal aldri åpne eller ødelegge slike kapsler. Cellcept er et im- munsupressivt middel som har vist seg å kunne gi misdannelser. Felleskatalogen angir at kapslene skal behandles med varsomhet, og må ikke åpnes, tygges eller knuses. Innholdet i kapslene må ikke innåndes, og innholdet må ikke komme $i$ kontakt med huden. Cytostatika er en preparatgruppe som gravide særlig må unngå, og enkelte av disse gis også som tabletter. Preparater med innhold av hormoner kan også være uheldig for gravide. Bicalutamid som brukes ved prostatakreft og finasterid til behandling av godartet forstørret prostata er eksempler på hormonpreparater som kan være fosterskadelige. Antibiotika er en stor legemiddelgruppe som kan utgjøre en helserisiko for dem som håndterer det, spesielt i form av antibiotikaallergi. Knusing av antibiotikatabletter vil gjøre helsepersonell mer utsatt for hudkontakt og innånding av partikler, og man bør iverksette tiltak for å beskytte personalet (2).

\section{Vond smak}

Mange legemidler smaker vondt. Filmdrasjering av tabletter gir dem en glatt overflate slik at de er lettere å svelge og smaken ikke blir så framtredende. Gelatinkapsler er spesielt godt egnet til å skjule vond smak på legemidler. Man ødelegger ikke virkningen av filmdrasjerte tabletter ved å knuse dem, og innholdet i vanlige kapsler kan tømmes ut og spises, men noen legemidler vil da smake veldig vondt.

\section{Informasjonskilder}

Denne artikkelen nevner noen spredte eksempler, men $i$ virkeligheten dreier det seg om et stort antall preparater som ikke kan knuses eller tygges. Det kan også være vanskelig å finne informasjon om

\section{«Mange legemidler skal svelges hele for å redusere risikoen for bivirkninger.»}

knusing av tabletter i Felleskatalogen. I en studie blant norske sykehjem oppga nesten 60 prosent av de 1037 avdelingene som svarte at informasjonen i Felleskatalogen om knusing/deling av legemidler enten var vanskelig å finne eller var uklar (3). Forskrivnings- og ekspedisjonsstøtte (FEST) er en database med legemiddelopplysninger utviklet av Legemiddelverket, og denne inneholder også opplysninger om tabletter kan knuses eller deles (4). Man er imidlertid avhengig av dataprogrammer der informasjonen fra FEST gjøres tilgjengelig. Apotek og tilsynsfarmasøyter bør være naturlige kilder å spørre når man er usikker på slike problemstillinger. Mange tilsynsfarmasøyter kan også bidra med oversikter over hvilke preparater som skal inntas på en bestemt måte. III

\section{LITTERATUR}

Wannebo W. Tablettknusing i sykehiem. Sykepleien forskning 2009:4:6-15. (www.sykepleien.no/forskning/forskningsartikkel/149622/tablettknusingi-sykehjem-en-sikkerhetsrisiko-for-pasienten)

2. Retningslinjer for håndtering av antimikrobielle midler i helsevesenet. IK2568/1997 fra Helsetilsynet. (www.helsetilsynet.no/upload/Publikasjoner/ veiledningsserien/haandtering_antimikrobielle_midler_ik-2568.pdf)

3. Kirkevold $\emptyset$, Engedal $K$. Legemiddelhåndtering i norske sykehjem med fokus på knusing av medikamenter. Sykepleien forskning 2010;5:16-25. (www. sykepleien.no/forskning/forskningsartikkel/337004/legemiddelhandteringi-norske-sykehjem-med-fokus-pa-knusing-av-medikamenter)

4. FEST - Forskrivnings- og ekspedisjonsstøtte. Hjemmesiden til Statens Legemiddelverk. (http://www.slv.no/templates/InterPage___-_82461. aspx) 